\title{
Seedling Emergence and Establishment of Annual Bluegrass (Poa annua) in Turfgrasses of Traditional and Creeping Perennial Ryegrass Cultivars
}

\author{
Roberta Masin and Stefano Macolino*
}

\begin{abstract}
Annual bluegrass is a cosmopolitan, cool-season grass that adapts to different environmental conditions. It is one of the main weeds of turfgrass, and its control is mainly achieved through chemical and cultural practices, although little importance is given to the competitive ability of turfgrass species or cultivars. A field study was performed in northeastern Italy from October 2012 to June 2014 to evaluate the competitive ability of selected perennial ryegrass cultivars to suppress emergence and establishment of annual bluegrass seedlings. Two creeping perennial ryegrasses ('CSI' and 'PPG-PR171') and two traditional cultivars ('Azimuth' and 'Presidio') were compared. In late autumn in both years, annual bluegrass was sown in a marked area $(30 \mathrm{~cm}$ by $30 \mathrm{~cm})$ in the turfgrass. Emerged seedlings were counted weekly, and emergence dynamics were modeled. In the second year, final density of annual bluegrass allowed to grow in turfgrass was also evaluated in summer. Results showed that both seedling emergence and density of annual bluegrass were significantly reduced by creeping perennial cultivars, supporting the hypothesis that these cultivars may reduce annual bluegrass establishment in turfgrass. Seedling emergence pattern of annual bluegrass did not differ in creeping and traditional cultivars of perennial ryegrass, suggesting the possibility of creating a general emergence model suitable in any turfgrass to help turfgrass managers in the control of this weed species.
\end{abstract}

Nomenclature: Annual bluegrass, Poa annua L. POAAN; perennial ryegrass, Lolium perenne L. Key words: Competition, emergence modeling, grass weeds, plant density, plant morphology.

\begin{abstract}
Poa annua es una gramínea de clima frío cosmopolita que se adapta a diferentes condiciones ambientales. Es una de la malezas más importantes en céspedes, y su control se alcanza principalmente mediante prácticas químicas y culturales, ya que se le da poca importancia a la habilidad de competencia de las especies y cultivares de céspedes. Se realizó un estudio de campo en el noreste de Italia desde Octubre 2012 a Junio 2014 para evaluar la habilidad de competencia de cultivares de Lolium perenne seleccionados para suprimir la emergencia y el establecimiento de plántulas de $P$. annua. Se comparó dos cultivares con propagación vegetativa (producción de tallos laterales) de L. perenne ('CSI' y 'PPG-PR171') y dos cultivares tradicionales ('Azimuth' y 'Presidio'). Al final del otoño en ambos años, se sembró $P$. annua en un área marcada (30 cm por $30 \mathrm{~cm}$ ) en el césped. Las plántulas emergidas fueron contadas semanalmente, y las dinámicas de emergencia fueron modeladas. En el segundo año, la densidad final de $P$. annua que creció en el césped fue también evaluada en el verano. Los resultados mostraron que tanto la emergencia de plántulas como la densidad de $P$. annua fueron significativamente reducidas por los cultivares con reproducción vegetativa, lo que apoya la hipótesis de que estos cultivares podrían reducir el establecimiento de $P$. annua en céspedes. El patrón de emergencia de $P$. annua no difirió entre los cultivares de $L$. perenne con propagación vegetativa y los tradicionales, lo que sugiere la posibilidad de que se puede crear un modelo de emergencia general válido en cualquier césped para ayudar a los profesionales en céspedes en el control de esta especie de maleza.
\end{abstract}

Annual bluegrass is one of the most problematic weeds in turfgrass. It negatively affects the aesthetic and functional value of both warm- and cool-season turfgrasses and can be competitive year-round (Flessner et al. 2014). The species germinates when soil temperatures range between 16 and $21 \mathrm{C}$, it

\footnotetext{
DOI: 10.1614 /WT-D-15-00070.1

* Assistant Professor and Assistant Professor, Department of Agronomy, Food, Natural Resources, Animals and Environment, University of Padova, Viale dell'Università 16, 35020 Legnaro (PD), Italy. Corresponding author's E-mail: roberta.masin@unipd.it
}

tolerates short mowing heights, and it produces a prolific seedhead, even close to the soil surface (Law et al. 1977; Matthew et al. 2013; Vargas and Turgeon 2004). The annual bluegrass blooming period occurs mainly with cool temperatures and short photoperiods, but it can bloom throughout the growing season (David 2003). These features enhance its diffusion in turfgrasses and contribute to the soil seed bank formation.

Annual bluegrass is a typical weed of intensively managed recreational turfgrasses, such as golf 
courses and athletics fields, but it can also be a problem in home lawns (McCullough 2012). The large number of visible seedheads, which characterize this species, disturbs the uniformity and playability of putting greens. In temperate regions, annual bluegrass represents the worst weed problem for golf course superintendents because of its high susceptibility to diseases and poor tolerance to heat and drought stress (Beard 2002; Brosnan et al. 2013; McCullough et al. 2005). Generally, annual bluegrass infestation is favored by frequent irrigation, short mowing height, and high nitrogenfertilization rates (Busey 2003).

Annual bluegrass control in high-value turfgrasses is basically obtained using PRE or POST herbicides. Several studies have evaluated the efficacy of different herbicides in suppressing annual bluegrass in creeping bentgrass (Agrostis stolonifera L.). These studies revealed that annual bluegrass control is rarely complete because of the long germination period, the limited efficiency of selective herbicides, and the influence of environmental conditions (Askew and McNulty 2014; Baldwin et al. 2012; Callahan and McDonald 1992; Kaminski and Dernoeden 2007; McElory 2011). Albeit methiozolin, a new herbicide, shows excellent control, multiple yearly applications are still crucial to maintain suppression of annual bluegrass (Askew and McNulty 2014; Koo et al. 2014). Other strategies investigated involve plant growth regulators (PGRs), which are used to suppress seedhead formation and plant growth. However, the efficiency of PGRs on annual bluegrass control often varies because it is strongly affected by the timing and frequency of treatments (Haguewood et al. 2013; Johnson and Murphy 1995, 1996; McCullough et al. 2005; Woosley et al. 2003).

A sustainable turfgrass system is expected to become an increasingly important issue worldwide, with increasing restrictions on management inputs, including the use of chemicals for weed control (Watkins et al. 2010). Chemical control is not only costly but also may increase a wide range of environmental risks involving people, wildlife, and water sources (Johnson 1994; Kristoffersen et al. 2008). To prevent environmental impacts and human health concerns, the European Union Directive 2009/128/EC produced guidelines that give priority to nonchemical methods (European Parliament 2009).

Basically, annual bluegrass infestation occurs in compacted and poorly drained soils and under high $\mathrm{P}$ and K soil levels (Goss et al. 1975; Waddington et al. 1978; Watschke et al. 1995), so turfgrass managers have to continuously monitor both physical and chemical conditions of the soil and work to reduce conditions that favor annual bluegrass establishment. Preventive and cultural strategies should thus be encouraged. Cultural practices to control annual bluegrass are mainly focused on soil fertility management, aeration, and drainage to reduce conditions that favor annual bluegrass.

One of the best ways to prevent weed infestation is the proper selection of turfgrass species at seeding. The choice should focus on species and cultivars with high competitive ability against weeds because it is known that differences in morphology and canopy traits have an important role for turfgrasses to outcompete weeds (Busey 2003; Johnson and Murphy 1996; Turgeon 2002). Nevertheless, little attention has been given to morphological properties of cultivars in preventing the spread of annual bluegrass in turfgrasses.

Because of its quick establishment and tolerance to close mowing, perennial ryegrass is one of the most common turfgrass species in cool climates (Goatley et al. 2008; Puhalla et al. 1999). New cultivars of perennial ryegrass with prostrate growth habits and lateral-spreading shoots (creeping-type) have recently been developed (Charbonneau and Brownbridge 2013). These cultivars, which potentially have higher competitive ability than the traditional cultivars, are going to be introduced on the Italian turfgrass market. However, to our knowledge, there are no studies to date that have described the effects of such cultivars on weed competition.

The objective of this study was to evaluate the competitive ability of creeping-type cultivars to limit annual bluegrass infestation. Because weed emergence prediction is essential for improving control by allowing the best solution to be selected (Masin et al. 2005a,b), the second objective was to study annual bluegrass emergence to evaluate the possibility of predicting the pattern of this weed species in turfgrass. 


\section{Materials and Methods}

Annual Bluegrass Emergence. A 2-yr field experiment was conducted in northeastern Italy to compare two traditional and two creeping perennial ryegrass cultivars for ability to suppress annual bluegrass emergence. Annual bluegrass emergence pattern was also observed, compared, and modeled in the four perennial ryegrass cultivars and in bare soil.

A field trial was performed from October 2012 to May 2013 and was repeated from October 2013 to May 2014 at the experimental farm of Padova University in Legnaro, Italy $\left(45.345952^{\circ} \mathrm{N}\right.$, $11.949544^{\circ} \mathrm{E} ; 8 \mathrm{~m}$ above sea level).

The soil was a loam texture (fulvi-calcaric Cambisol; FAO 2006) containing 49\% silt, $16 \%$ clay, and $35 \%$ sand, with a $\mathrm{pH}$ of $8.0,2.6 \%$ organic matter, an Olsen extractant $\mathrm{P}$ content of $4.9 \mathrm{mg}$ $\mathrm{kg}^{-1}$, an exchangeable $\mathrm{K}$ content of $162 \mathrm{mg} \mathrm{kg}^{-1}$, and a $\mathrm{C}$ to $\mathrm{N}$ ratio of 10.8 . The climate is subhumid with a mean annual rainfall of about $850 \mathrm{~mm}$, which is fairly uniformly distributed throughout the year. The area has a mean annual temperature of 15.6 C with temperature increases from January (average minimum value: $1.2 \mathrm{C}$ ) to August (average maximum value: $32.6 \mathrm{C}$ ).

Four cultivars of perennial ryegrass were sown on October 3, 2012, and October 2, 2013, at a rate of $25 \mathrm{~g} \mathrm{~m}^{-2}$ in soil previously covered by the turfgrass cultivars of cool-season species, perennial ryegrass, Kentucky bluegrass (Poa pratensis L.), and tall fescue [Lolium arundinaceum (Schreb.) S.J. Darbyshire]. The cultivars used included two creeping types, 'CSI' ('New Orleans' in Europe) and 'PPG-PR $171^{\prime}$, and two traditional types, 'Azimuth' and 'Presidio'. The experimental design was a randomized complete block with three replications and $1 \mathrm{~m}$ by $2 \mathrm{~m}$ plots. An additional plot with bare soil was used as a control to determine emergence of annual bluegrass without competition from turfgrass.

Before sowing, the plot area was fertilized with 50 $\mathrm{kg} \mathrm{N} \mathrm{ha}{ }^{-1}, 150 \mathrm{~kg} \mathrm{P}_{2} \mathrm{O}_{5} \mathrm{ha}^{-1}$, and $150 \mathrm{~kg} \mathrm{~K}_{2} \mathrm{O}$ $\mathrm{ha}^{-1}$. Subsequent fertilization consisted of $150 \mathrm{~kg} \mathrm{~N}$ $\mathrm{ha}^{-1}$ using ammonium nitrate $(27 \% \mathrm{~N})$ split equally between three applications in November, March, and May.

During the establishment phase, plots were irrigated daily with 3 to $5 \mathrm{~mm}$ of water using a sprinkler-irrigation system. In both years, during growing periods from October to November and from March to April, plots were mowed weekly with a rotary mower (Honda HRX 476 SX E, Honda Motor Co. Ltd., Tokyo, Japan) at a height of $35 \mathrm{~mm}$, and clippings were removed.

Mature seeds of annual bluegrass were harvested in summer 2013 from natural populations growing on the farm. In December, after perennial ryegrass cultivars reached complete establishment, annual bluegrass was sown at a rate of $3.0 \mathrm{~g} \mathrm{~m}^{-2}$ (about 7,000 seeds) in a marked area $(30 \mathrm{~cm}$ by $30 \mathrm{~cm})$ in the middle of each plot. From the first detected emergence, the number of emerged annual bluegrass seedlings was counted and removed weekly with minimum soil disturbance.

Daily precipitation and soil temperature at 0 and $10 \mathrm{~cm}$ were collected during the experiments from ARPA (Regional Environmental Protection Agency of Veneto) meteorological stations located in close proximity to the plots.

Annual Bluegrass Density. In December of the second year, an additional area $(30 \mathrm{~cm}$ by $30 \mathrm{~cm})$, sown with annual bluegrass, was marked out in each plot. In this area, annual bluegrass was allowed to grow in turfgrass until June, when the density (number of plants per square meter) was evaluated.

Statistical Analysis. Annual Bluegrass Emergence. Factorial ANOVA was performed using Statistica software (version 10, StatSoft, Tulsa, OK) to analyze the effect of the cultivar on total emerged seedlings. The main factors (cultivar and year) and the cultivar by year interaction were detected, and means were separated using Fisher's protected LSD test at $\alpha=0.05$.

The percentage of cumulated emergence (CE; cumulated and normalized to $100 \%$ ) was modeled for each year with a Gompertz function, as follows:

$$
C E_{i}=100 \exp \left[-a \exp \left(-b d a y_{i}\right)\right]
$$

where $a$ is related to a time lag before emergence starts, and $b$ is related to the slope of the curve. In 2013, the similarity of emergence dynamics in different turfgrasses and bare soil allowed all emergence data to be considered together; in 2014, only weed emergence in turfgrasses was modeled (considering all data together), whereas weed emergence in bare soil was not included in the analysis. 
Weed emergence model performance was evaluated with an efficiency index (EF) (Loague and Green 1991), which was calculated as follows:

$$
\begin{aligned}
E F= & {\left[\sum_{i=1}^{n}\left(O_{i}-\bar{O}\right)^{2}-\sum_{i=1}^{n}\left(P_{i}-O_{i}\right)^{2}\right] / } \\
& {\left[\sum_{i=1}^{n}\left(O_{i}-\bar{O}\right)^{2}\right] }
\end{aligned}
$$

where $P_{i}$ is the predicted value, $O_{i}$ is the observed value, and $\bar{O}$ is the mean of the observed values. The $E F$ ranges from 1 to a negative value, and an $E F$ of 1 indicates exact predictions.

Annual Bluegrass Density. ANOVA was performed to determine whether the final density of annual bluegrass allowed to grow in the turfgrass differed across turfgrass cultivars. Means were compared using Fisher's protected LSD test at $\alpha=0.05$.

\section{Results and Discussion}

Annual Bluegrass Emergence. ANOVA identified a significant effect of cultivar $(\mathrm{P}=0.016)$ and cultivar by year interaction $(\mathrm{P}=0.032)$ on annual bluegrass emergence, whereas the year did not show a significant effect. Emergence of annual bluegrass in Presidio was significantly higher than it was in creeping cultivars in 2013, whereas in 2014, Presidio showed the same ability as the creeping cultivars to reduce annual bluegrass emergence (Figure 1). Conversely, the difference between Azimuth and creeping cultivars was not significant in 2013, whereas, in 2014, the competitiveness of Azimuth against annual bluegrass emergence was lower than all other cultivars (Figure 1). This different competitiveness against annual bluegrass of the two traditional cultivars in 2013 and 2014 may be due to the differences in meteorological conditions between the 2 yr (Figure 2); 2014 was warmer than 2013, especially in the early part of the year from January to April, and 2014 was drier, with limited rainfall in March and April, whereas rainfall was abundant during March and early April in 2013. These differences may have affected the cultivars' performances by changing the competitive balance between turfgrass and weed.

Nevertheless, although the traditional cultivars showed alternating behavior in the $2 \mathrm{yr}$, the creeping cultivars maintained a high competitive ability against annual bluegrass in both years.

The emergence pattern of annual bluegrass (expressed as the percentage of the total emergence
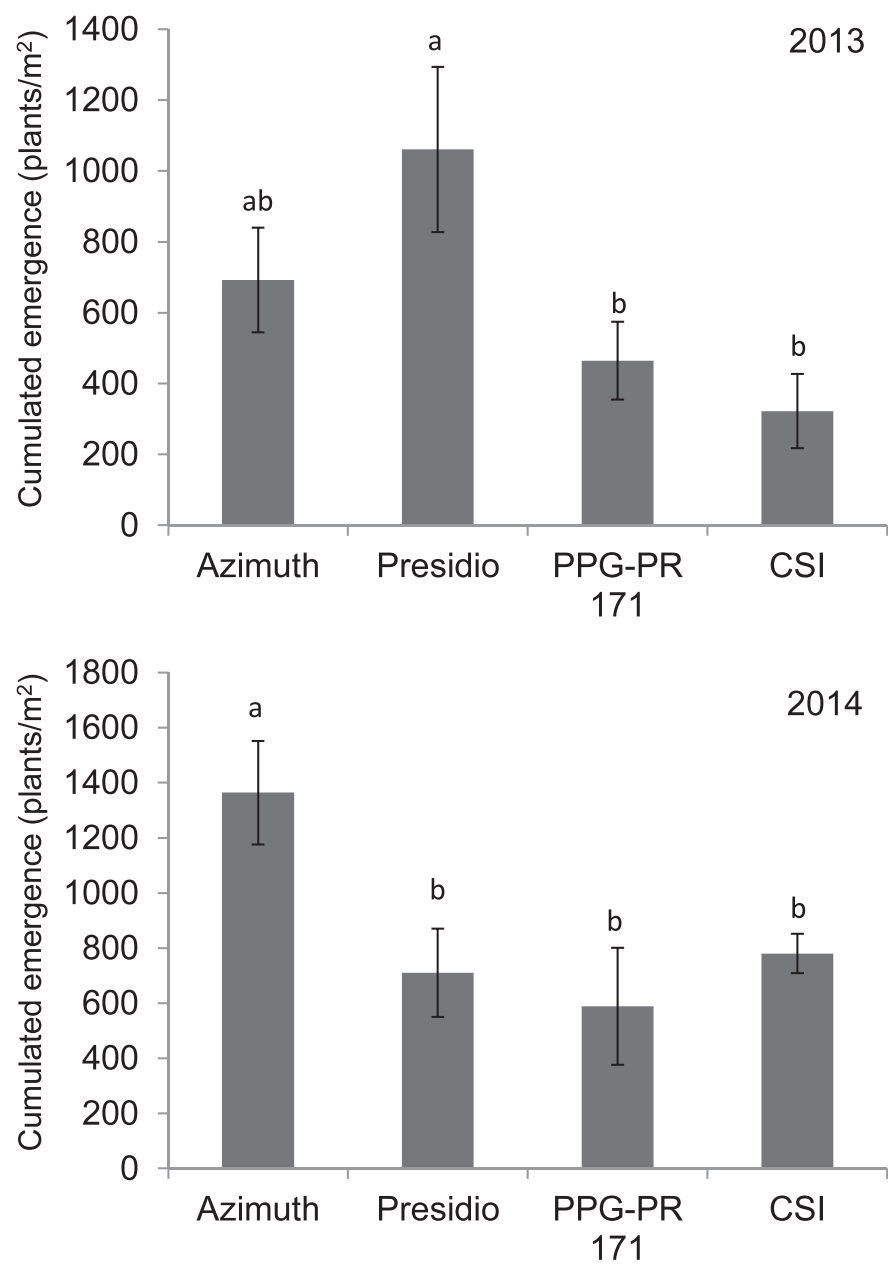

Figure 1. Cumulated emergence of annual bluegrass in four perennial ryegrass cultivars in 2013 and 2014. Vertical bars represent standard errors; different letters indicate significant differences according to Fisher's protected LSD test $(\mathrm{P}<0.05)$.

at the end of the season) did not differ in creeping and traditional cultivars or in bare soil in 2013 (Figure 3). It was possible to model weed emergence with just one function, as confirmed by the high efficiency of the estimation $(\mathrm{EF}=0.96)$. In 2014, one model was used to describe the weed emergence pattern in turfgrass with high efficacy $(\mathrm{EF}=0.98)$, but emergence in bare soil showed steeper dynamics with a higher slope, so emergence data in bare soil were not included in the model.

In 2014, weed emergence occurred earlier than it did in 2013 (Figure 3). This is easily explained by the higher soil temperature in January and February 2014 (Figure 2), which determined the faster heatunit accumulation (thermal time) needed for the germination-emergence process. Although emergence began earlier in 2014, the emergence rate was 

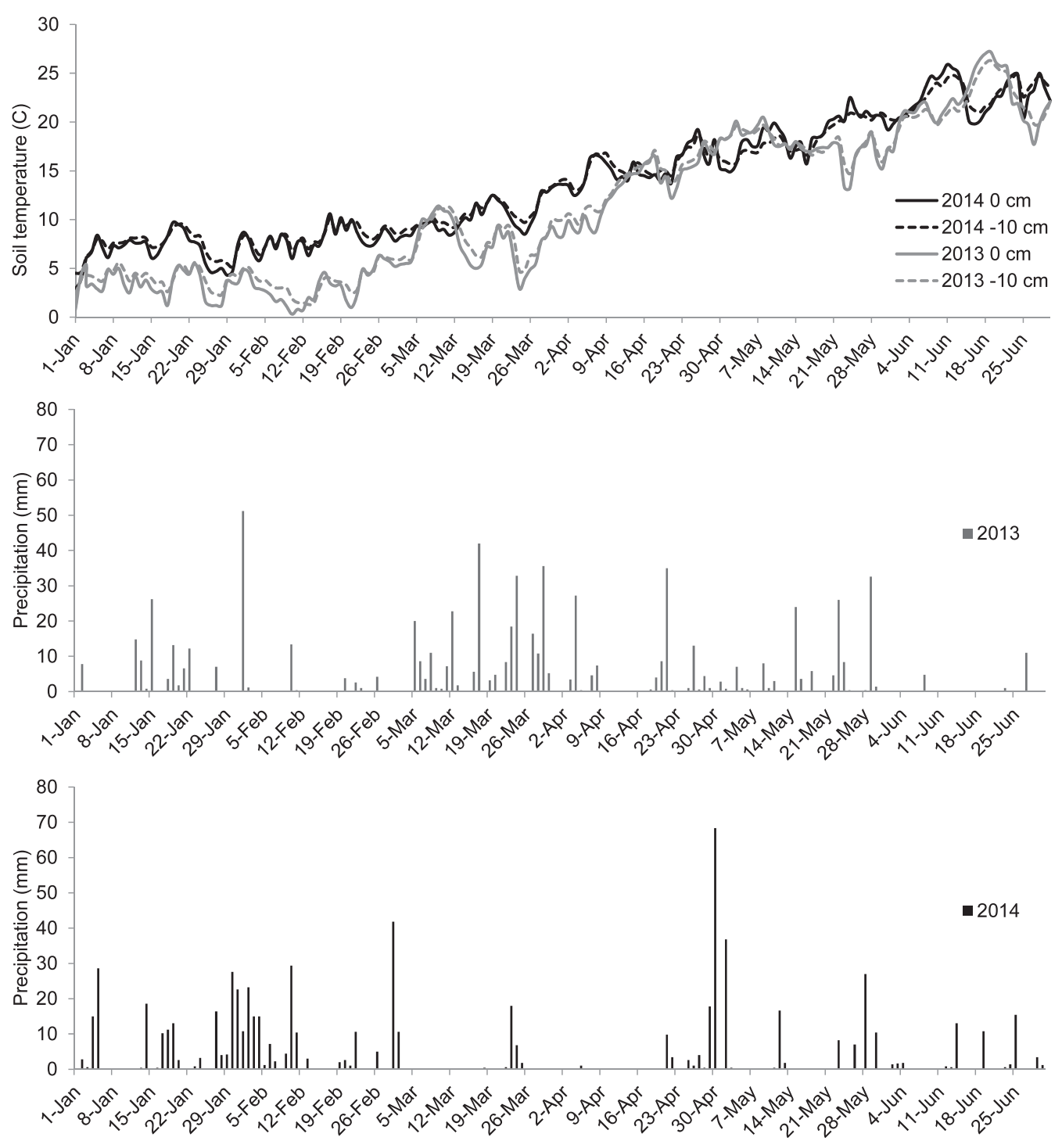

Figure 2. Daily soil temperature under turfgrass $(0 \mathrm{~cm}$ and $-10 \mathrm{~cm})$ and daily precipitations in 2013 and 2014 .

slower in 2014 than it was in 2013, as shown by the shallower curve in 2014 (Figure 3). In 2013, annual bluegrass showed a very speedy emergence that only lasted $1 \mathrm{mo}$ (from the end of February to the end of March), whereas, in 2014, it lasted 2.5 mo (from the middle of February to the end of April). The short emergence period observed in 2013 may be explained by the intense rainfall and rising temperature in March that created optimal conditions for annual bluegrass emergence, whereas limited rainfall in March 2014 slowed weed emergence.

Even though annual bluegrass pattern was different in 2013 than it was in 2014, the same dynamics were observed in all the perennial ryegrass cultivars tested in each year and also in bare soil in 2013. In fact, a single model was able to describe weed emergence with high EF. These findings are important because they support the idea of a possible future prediction of emergence dynamics for this species. The fact that cultivars did not differently influence weed emergence pattern suggests the possibility of creating a general model suitable in any turfgrass. In this study, the model was based on days, and different values for the equation parameters were used in the 2 yr. Using hydrothermal time as an independent variable, it is likely that the same model equation may be able to describe emergence dynamics in years with different meteorological conditions. Indeed soil temperature 


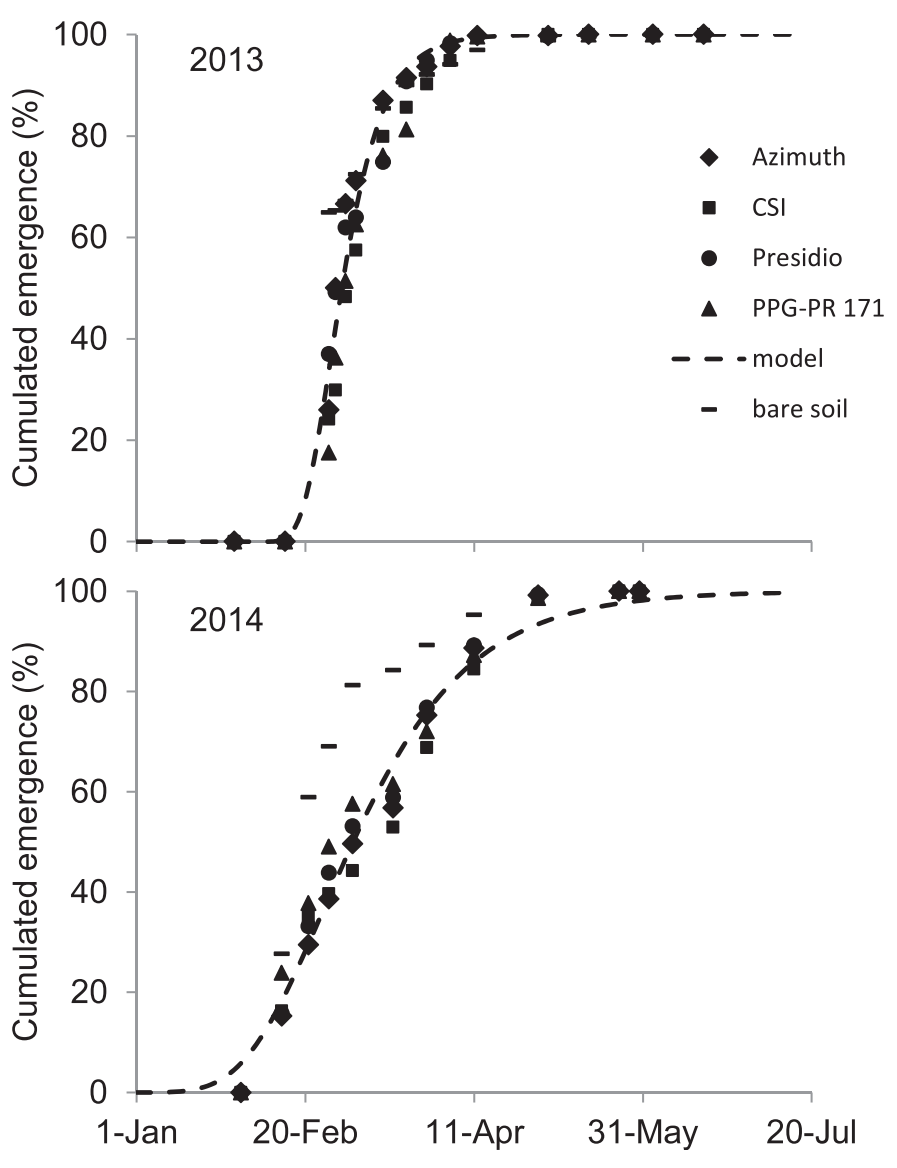

Figure 3. Emergence dynamics (percentage) of annual bluegrass in four perennial ryegrass cultivars and in bare soil in 2013 and 2014. Observations and model (dotted line). Estimated regression equations are $y=100 \exp \{-305.4[\exp (-0.101 x)]\}$ for 2013 and $y$ $=100 \exp \{-10.5[\exp (-0.042 x)]\}$ for 2014 .

and soil water potential are considered the main factors driving germination-emergence process (Grundy 2003).

The fact that cultivars differentially reduced annual bluegrass emergence (Figure 1), whereas weed emergence dynamics were the same in all cultivars, demonstrates that the turfgrass competitiveness was of the same intensity during the entire weed-emergence period. This was particularly evident in 2013, when annual bluegrass emergence dynamics were the same in turfgrass and in bare soil, where there was no competition for the weed and final accumulated emergence was very high (more than 5,000 plant $\mathrm{m}^{-2}$ ).

In 2014, the emergence dynamics in turfgrass and in bare soil were different. The reason may be the limited March to April rainfall that slowed the emergence more in bare soil than it did in turfgrass because the turfgrass cover may have maintained

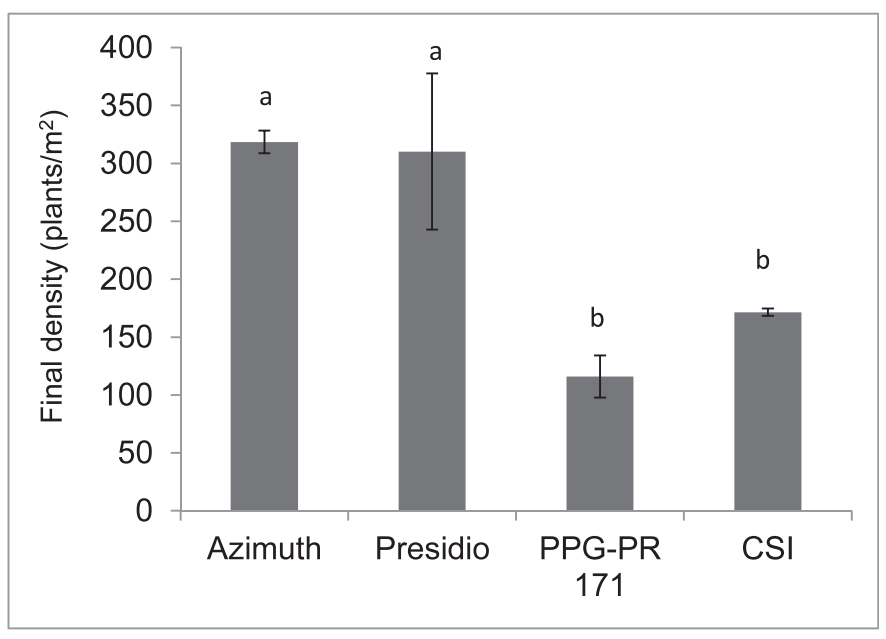

Figure 4. Final density of annual bluegrass allowed to grow in different turfgrasses composed of four perennial ryegrass cultivars in 2014. Vertical bars represent standard errors; different letters indicate significant differences according to Fisher's protected LSD test $(\mathrm{P}<0.05)$.

higher soil water potential in the near-surface layer (the seed germination zone).

Annual Bluegrass Density. The effect of cultivar on final annual bluegrass density was significant ( $P$ $=0,008)$. The final density of annual bluegrass in turfgrass was significantly lower in the creeping cultivars (CSI and PPG-PR 171), confirming their higher competitiveness against the weed (Figure 4). The two creeping cultivars of perennial ryegrass did not differ from one another. These results confirmed those obtained observing the cultivars' capacity to contain weed emergence. Interestingly, the number of plants counted at the end of the spring season is much lower than emerged seedlings counted during the emergence period (Figures 1 and 4). It appears that only some annual bluegrass seedlings were able to become adult plants, with mortality from seedling to adult plant at about $70 \%$.

In conclusion, the results of this research appear to support the hypothesis that the creeping cultivars of perennial ryegrass may reduce annual bluegrass infestation in turfgrass. Intuitively, it seems that differences in morphological features among cultivars affect factors involved in the spring germination-emergence process and the persistence of annual bluegrass. However, properly focused research is required to investigate the specific traits involved because crop competitiveness cannot be attributed to a single plant trait; rather, it is a sum of 
interactions of several plant characteristics (Asif et al. 2014). The results reported in this article are from a 2-yr experiment, so additional research over several years is needed to confirm the higher weed competitiveness of the creeping-type cultivars. Moreover, this research showed that the weed emergence pattern was the same in four different monostands of perennial ryegrass, and in each year, a single equation was able to explain them. This is the first step toward the construction of an annual bluegrass emergence predictive model, an essential tool for improving the control of weed species by allowing the best treatment timing to be selected for both PRE and POST applications (Masin et al. 2012).

\section{Acknowledgments}

The research was financed by Padova University: "Research Project 60\% 2013": "Capacità competitiva di alcuni loietti a portamento prostrato nei confronti di Poa annua." The authors thank the seed company Padana Sementi Elette srl for providing the seed for the perennial ryegrass cultivars.

\section{Literature Cited}

Asif M, Iqbal M, Randhawa H, Spaner D (2014) Managing and Breeding Wheat for Organic Systems. New York: Springer. $76 \mathrm{p}$

Askew SD, McNulty BMS (2014) Methiozolin and cumyluron for preemergence annual bluegrass (Poa annua) control on creeping bentgrass (Agrostis stolonifera) putting greens. Weed Technol 28:535-542

Baldwin CM, Brede AD, Mayer JJ (2012) 'JS501' and 'Replay' perennial ryegrass glyphosate tolerance and rates required for annual bluegrass (Poa annua L.) control. Hortscience 47:932935

Beard JB (2002) Turf Management for Golf Courses. 2nd ed. Hoboken, NJ: J. Wiley. Pp. 437-584

Brosnan JT, Henry GM, Breeden GH, Cooper T, Serensits TJ (2013) Methiozolin efficacy for annual bluegrass (Poa annua) control on sand- and soil-based creeping bentgrass putting greens. Weed Technol 27:310-316

Busey P (2003) Cultural management of weeds in turfgrass: a review. Crop Sci 43:1899-1911

Callahan LM, McDonald ER (1992) Effectiveness of bensulide in controlling two annual bluegrass (Poa annua) subspecies. Weed Technol 6:97-103

Charbonneau P, Brownbridge M (2013) Rhizomatous tall fescue and regenerative perennial ryegrass performance in Ontario: year 1. Sports Turf Manag 26:14-18
David RH (2003) Annual Bluegrass L. (Poa annua L.) Pages 3951 in Casler MD, Duncan RR, eds. Turfgrass Biology, Genetics, and Breeding. Hoboken, NJ: J. Wiley

European Parliament (2009). Directive 2009/128/EC of the European Parliament and of the Council.

[FAO] Food and Agricultural Organization of the United Nations (2006) World Reference Base for Soil Resources 2006: A Framework for International Classification, Correlation and Communication. Rome: FAO World Soil Res Rep 103. $145 \mathrm{p}$

Flessner ML, McElroy JS, Wehtje GR (2014) Annual bluegrass (Poa annua) control in glyphosate-resistant perennial ryegrass overseeding. Weed Technol 28:213-224

Goatley M, Askew S, Ervin E, McCall D, Studholme B, Schultz P, Horvath B (2008) Sports turf management in the transition zone. Blacksburg, VA: Pocahontas

Goss RL, Brauen SE, Orton SP (1975) The effects of N, P, K, and S on Poa annua L. in bentgrass putting green turf. J. Sports Turf Res Inst 51:74-82.

Grundy AC (2003) Predicting weed emergence: a review of approaches and future challenges. Weed Res. 43:1-11.

Haguewood JB, Song E, Smeda RJ, Moss JQ, Xiong X (2013) A suppression of annual bluegrass seedheads with mefluidide, ethephon, and ethephon plus trinexapac-ethyl on creeping bentgrass greens. Agron J 105:1832-1838.

Johnson BJ (1994) Biological control of annual bluegrass with Xanthomonas campestris pv. poannua in bermudagrass. Hortscience 29:659-662

Johnson BJ, Murphy TR (1995) Effect of paclobutrazol and flurprimidol on suppression of Poa annua spp. reptans in creeping bentgrass (Agrostis stolonifera) greens. Weed Technol 9:182-186

Johnson BJ, Murphy TR (1996) Suppression of a perennial subspecies of annual bluegrass (Poa annua spp. reptans) in a creeping bentgrass (Agrostis stolonifera) greens with plant growth regulators. Weed Technol 10:705-709

Kaminski JE, Dernoeden PH (2007) Seasonal Poa annua L. emergence patterns in Maryland. Crop Sci 47:775-781

Koo SJ, Hwang KH, Jeon MS, Kim SH, Lim J, Lee DG, Cho NG (2014) Methiozolin [5-(2,6-difluorobenzyl)oxymethyl-5methyl-3,3(3-methylthiophen-2-yl)-1,2-isoxazoline], a new annual bluegrass (Poa annua L.) herbicide for turfgrasses. Pest Manag Sci 70(1):156-62

Kristoffersen P, Rask AM, Grundy AC, Franzen I, Kempenaar C, Raisio J, Schroeder H, Spijker J, Verschwele A, Zarina L (2008) A review of pesticide policies and regulations for urban amenity areas in seven European countries. Weed Res 48:201214

Law R, Bradshaw AD, Putwain PD (1977) Life-history variation of Poa annua. Evolution 31:233-246

Loague K, Green RE (1991) Statistical and graphical methods for evaluating solute transport models: overview and application. J Contam Hydrol 7:51-73

Masin R, Zuin MC, Archer DW, Forcella F, Zanin G (2005a) WeedTurf: a predictive model to aid control of annual summer weeds in turf. Weed Sci 53:193-201

Masin R, Zuin MC, Zanin G (2005b) Phenological observations on shrubs to predict weed emergence in turf. Int J Biometeorol $50: 23-32$ 
Masin R, Loddo D, Benvenuti S, Otto S, Zanin G (2012) Modeling weed emergence in Italian maize field. Weed Sci 60:254-259

Matthew DJ, Yelverton FH, Gannon TW (2013) Annual bluegrass (Poa annua) control in creeping bentgrass putting greens with Amicarbazone and Paclobutrazol. Weed Technol 27:520-526

McCullough PE (2012) Annual Bluegrass Control in Residential Turfgrass. Athens, GA: UGA Cooperative Extension Bulletin 1394. $4 \mathrm{p}$

McCullough PE, Hart SE, Lycan DW (2005) Plant growth regulator regimens reduce Poa annua populations in creeping bentgrass. Appl Turfgrass Sci 2(1). DOI:10.1094/ ATS-2005-0304-01-RS

McElory JS, Breeden GK, Wehtje G (2011) Evaluation of annual bluegrass control programs for bermudagrass turf overseeded with perennial ryegrass. Weed Technol 25:58-63

Puhalla J, Krans J, Goatley M (1999) Sports Fields: A Manual for Design, Construction and Maintenance. Hoboken, NJ: J. Wiley. $464 \mathrm{p}$

Turgeon AJ (2002) Turfgrass Management. 6th edn. Upper Saddle Brook, NJ: Prentice Hall. 400 p
Vargas JM, Turgeon AJ (2004) Poa annua: Physiology, Culture, and Control of Annual Bluegrass. Hoboken, NJ: J. Wiley. $165 \mathrm{p}$

Waddington DV, Turner TR, Duich JM, Moberg EL (1978) Effect of fertilization on 'Pencross' creeping bentgrass. Agron J 70:713-718

Watkins E, Hollman AB, Horgan BP (2010) Evaluation of alternative turfgrass species for low-input golf course fairways. Hortscience 45:113-118.

Watschke TL, Dernoeden PH, Shetlar DJ (1995) Managing Turfgrass Pests. Boca Raton, FL: Lewis (CRC). 361 p

Woosley PB, Williams DW, Powell AJ (2003) Postemergence control of annual bluegrass (Poa annua spp. reptans) in creeping bentgrass (Agrostis stolonifera) turf. Weed Technol 17:770-776

Received May 18, 2015, and approved October 4, 2015.

Associate editor for this paper: Barry Brecke, University of Florida 